\title{
Construction and Innovation of Practical Teaching System of Ideological and Political Theory Course in Independent College from the Perspective of Synergetic Education
}

\author{
Yao Xiayuan \\ Beijing University of Posts and Telecommunications, China, Beijing 102100
}

Keywords: ideological and political education; counselor; cooperative education; independent college; practice education

\begin{abstract}
The construction and innovation of the ideological and political education teaching system is an effective way to attain the goal of the cultivation of advanced applied talents in independent colleges. The innovative ideological and practical teaching system of independent colleges must adhere to the principle of people-oriented, teaching students in accordance with their aptitudes, and work hard in everyday life, close to majors, integration of production and education, and service in local areas, and highlight the practical characteristics of independent colleges in the practical teaching of ideological and political education. Cooperation education is fully launched. Ideological and political teachers and instructors are front-line ideological workers. Under the challenge of the new situation of national education and the change of students' constitution, the connection and complementarity between the two become more and more important and urgent. The practical teaching of ideological and political education in independent colleges must produce realistic results. It will inevitably require a consensus between the two to reach the concept of consensus, team building, and resource sharing, and promote the normalization of collaborative education to ensure that "Strengthening Moral Education and Cultivating People" are implemented.
\end{abstract}

\section{Introduction}

As the focus of ideological and political education reform, practical teaching directly affects the effectiveness of ideological and political education and affects the quality of talent training. Currently, there are 266 independent colleges in China, with more than 2.6 million registered students. Responsibility for personnel training is significant. However, practical teaching of ideological education in independent colleges is mostly in the initial stage of development. Due to insufficient attention, limited funding, poor teacher resources, unclear characteristics, and the separation of content from students' professional background, the teaching effect is not optimistic. Students' ideological and political quality is uneven. It seeks to provide new ideas for the reform of practical teaching in the ideological and political education of independent colleges, and to improve the effectiveness of the ideological and political education and moral education work.

\section{The Orientation of Ideological and Political Teaching Practice in Independent Colleges and Application-oriented Features}

The independent college is a higher education aiming at cultivating applied and compound talents. Its application characteristics determine that practical teaching is an important part of independent college education. We believe that the key to promoting the teaching of ideological and political education in independent colleges lies in clarifying its objectives andemphasis, highlighting the applied characteristic.

First, we should correctly understand the purpose of applied education. The independent college is a higher education at the level of managing a school which focuses on applied education in the nature of schooling. Therefore, the primary task of independent college education should be "education", followed by "application-oriented education." Second, we should correctly understand the "application of the learning" of ideological and practical education in independent colleges. In 
the context of applied education, ideological and political education courses are often put in a very awkward position. The importance is often mentioned. However, their status in practical education operation is not high. The reason is that "application of the learning" output of the practice teaching of ideological and political course is not observable. However, practice teaching of ideological and political classes is "wise use" that seems to be useless. Through practice, it cannot only educate students on Marxist theory, but also help them master the correct world outlook and methodology.

\section{Promoting the Cooperative Education of Ideological and Political Teams is the Basis for Realizing the Integration of Human Resources}

\subsection{Establish a top-level cooperative education agency}

At present, ideological work teams of most independent colleges belong to different departments and are often irresponsible for each other, which has led to a serious disconnect between the ideological and political theory education and students' daily ideological and political education, and sometimes even mutual interference. In this regard, the independent college may try to establish a leading group for collaborative education based on the leadership of the school party committee directly at the school level, break the management system barriers, and establish and improve the organizational security and institutional foundations, and provide the necessary hardware and software conditions and facilities for the coordination and education of human resources. At present, independent colleges have established an ideological education coordination center. The center leadership group is designated by the school party committee. An office is set up to be responsible for the construction and practical operation of the information sharing platform for ideological and political work, and to establish a linkage mechanism for the practice of in-class teaching practice, the second classroom practice and the social practice internship platform outside school, and to pay more attention to school policies, funds, and political education .

\subsection{Integrate two first-line politicians}

In 2015, the Ministry of Education proposed to "promote the organic combination of ideological and political practice teaching and college students' social practice activities, integrate ideological and political teacher and counselor teams, and participate in organizing and guiding practical teaching together." Therefore, integrate ideological and political practice teaching with daily ideological and political education practice activities for university students to integrate front-line ideological and political work teams will effectively solve the problem of the ideological and political education that prevails in independent colleges and universities does not meet the daily ideological and political education of university students. At present, some independent colleges have designed $a$ " $1+x$ " teacher model for ideological and ethical teaching based on two front-line ideological teams. "1" is an ideological and political teacher, and "x" are a counselor. Other ideological workers. The ideological and political teachers coordinated the students' everyday teaching activities, and counselors and other ideological workers fully cooperated and fully

implemented them. At the same time, they called for a school party and government cadres to participate in the "x" brainstorming reserve.

\subsection{Professional teachers into the political team}

From the research situation, independent college students generally feel weak for practical teaching of ideological and political education. One of the principal reasons is the content is separate from the professional background of students. Based on that, it is urgent and practical to integrate practical teaching of ideological and political course with professional background. One requires that professional teachers who serve as part-time counselors actively carry out professional practice teaching that is closely related to the current political background and enhance the ideological nature of professional course. The ideological and political teachers actively understand the professional syllabus and teaching plan, and carry out ideological and practical teaching combined with a professional background. The combination of the two will enhance students' sense 
of mission towards professional development and the development of the country's development, promote students' re-understanding and positioning of ideological and political classes, enhance the professional teachers' sense of political mission, and to a certain extent, reduce the current situation in independent colleges. The vague sense of job burnout among ideological and political teachers has increased their sense of value.

\section{Optimizing Practice Resources and Achieving All-round Development of Students are Key Points}

\subsection{Develop ideological and practical teaching resources in ideological school to promote daily knowledge and practice.}

The first is the development of material resources, including places related to student learning, such as various practical teaching platforms, libraries, school history halls, etc., which are related to students'daily life, such as university student activity centers, canteens, dormitory rooms, and There are various cultural landscapes and natural landscapes related to school appearance. The second is the integration of practical activities in schools, focusing on the development of campus cultural activities closely related to the content of ideological and political courses, such as various humanistic competitions, major festival commemorative activities, and college student science and technology innovation activities. The successful holding of large-scale, politically-educated campus cultural activities often results in unexpected educational effects for our students. The third is the development of hidden resources, including the school training school song, school discipline, school style, school culture, cultural atmosphere, school philosophy, customary norms,teachers' morality, administrative management and logistics services staff behavior model etc.

\subsection{Development and professional combination of ideological and political practice teaching resources, promote professional courses and ideological and political courses}

The Ministry of Education's "Innovation Plan for the Construction of Ideological and Political Theory Courses in Colleges and Universities" pointed out that there are not many means for reform and innovation, and the bottlenecks that limit the effectiveness of targeted ideological and political theories need to be broken. Therefore, in practical teaching of ideological and political courses, the mutual penetration between ideological and political education and student professional education needs to be Intensified, professional-related knowledge and ideas needs to be integrated in the practical teaching of ideological and political courses. Ideological and political education need to be integrated in practical teaching of professional courses too. From the perspective of ideological and practical education reform and innovation, we should focus on the practical teaching of ideological and political classes that are actively promoted in combination with majors. According to the finding of research, students'evaluation and feedback on the practical effectiveness of ideological and political practice teaching is mainly due to its professional development and personal development. From the research situation, the students' evaluation and feedback on the actual effectiveness of ideological and political practice teaching is mainly due to its role in professional development and personal growth. According to this feedback, one of the important tasks of the ideological and political class practical teaching is to design practical teaching activities from the students' professional needs and career development, improve the pertinence of teaching, and improve students' sense of acquisition.

\subsection{Combining regional characteristics with the integration of production and education to serve local communities}

Under the background of "New Engineering”, independent colleges have intensified the students' internship training outside the university. Based on this trend, the ideological and political practice teaching can be integrated with the students' professional internships and training. Through careful design and careful organization, students can simultaneously complete ideological and political lesson practice topics in their professional practice. The ideological and political practice teaching 
process can be implemented by ideological and political teachers, professional teachers, and corporate mentors to collaboratively design ideological and practical teaching plans, and strive to conduct a comprehensive assessment of students' professional qualities and ideological and political qualities, and strive to cultivate the professionalism and craftsmanship that talent must possess. At present, a few independent colleges have formed a brand-new CDIO engineering education model and talent literacy assessment system, and affirmed the necessity of ideological and political education in the cultivation of advanced applied talents, and then put forward specific norms and requirements: at the practical teaching level, ideological and political teachers are required to actively investigate the requirements for the talent literacy of the "New Engineering" and determine the objectives of practical teaching; and actively listen to the suggestion of objectives, contents, and methods of the practical teaching of the ideological and political classes.

\section{Conclusion}

We need to identify breakthroughs and focus points for the specific practical needs of student groups from different majors in different grades, clarify key points and difficulties in practical teaching of ideological and political subjects, and focus on cultivating students' ideological and political qualities and fostering ideological and political awareness. In this process, ideological and political workers play an important role in the ideological and political education core team. Integrate effectively the practical resources of the three teams, promote integration of daily knowledge and action, integrate with major actively, and strengthen school-enterprise cooperation. Plus the integration of production and education, the service of localities. All of these make the ideological and political education in independent colleges to highlight their own characteristics and advantages, and refresh its vigor and vitality.

\section{References}

[1] Taking the cultivation and promotion of the core values of socialism as the foundations project for the concentration of souls, gathering strength, and strengthening the foundation of strength [N]. Guangming Daily, 2014-02-26(1).

[2] Several opinions on strengthening further the practice of education in Colleges and Universities [Z]. Teaching ideology and politics, (2012) No. 1.

[3] Comment from Education Department of the Propaganda Department of the CPC Central Committee on Further Strengthening and Improving Ideological and Political Theory Courses in Institutions of Higher Education [Z]. Teaching Social Politics [2005] No. 5.

[4] Tian Zhengping, Li Xiaoxian, Huang Yanpei. Education Theory Elections [M]. Beijing: People's Education Press, 1993: 53.

[5] Institutional Innovation Plan for Ideological and Political Theory Courses in Institutions of Higher Learning [Z]. Teaching Social Sciences (2015) No. 2. 